\title{
ANTIOXIDANT AND ANTIHEPATOMA ACTIVITIES OF PALM OIL EXTRACT
}

\author{
SHU-JING WU ${ }^{1}$ and LEAN TEIK NG ${ }^{2,3}$ \\ ${ }^{1}$ Department of Health and Nutrition \\ Chia-Nan University of Pharmacy and Technology \\ Tainan, Taiwan \\ ${ }^{2}$ Department of Biotechnology \\ Tajen University \\ Pingtung, Taiwan \\ Submitted for Publication May 4, 2006 \\ Revised Received and Accepted August 15, 2006
}

\begin{abstract}
Palm oil extract (POE) at different concentrations $(0.1-500 \mu \mathrm{g} / \mathrm{mL})$ was evaluated for antioxidant and antihepatoma activities. Results showed that $P O E$ exhibited a greater antioxidant activity than $\alpha$-tocopherol in all model systems tested. At concentrations of 0.1-100 $\mu \mathrm{g} / \mathrm{mL}$, POE showed a superoxide radical scavenging activity ranging from 50.6 to $100 \%$, with an $I C_{50}$ value $(0.09 \mu \mathrm{g} / \mathrm{mL})$ lower than $\alpha$-tocopherol $(0.51 \mu \mathrm{g} / \mathrm{mL})$. In the xanthine oxidase inhibition test, $P O E\left(I C_{50}=0.67 \mu \mathrm{g} / \mathrm{mL}\right)$ also exhibited a stronger inhibitory effect on xanthine oxidase activity than $\alpha$-tocopherol $\left(I C_{50}=0.83 \mu \mathrm{g} / \mathrm{mL}\right)$. At concentrations of $0.1 \mu \mathrm{g} / \mathrm{mL}$ and above, POE showed significant ability in inhibiting the oxidative damage to lipids induced by ascorbate-Fe $\mathrm{F}^{2+}$ than $\alpha$-tocopherol in rat liver $\left(I C_{50}=0.53 \mu \mathrm{g} / \mathrm{mL}\right.$ versus $\left.0.94 \mu \mathrm{g} / \mathrm{mL}\right)$, brain $\left(I C_{50}=0.10 \mu \mathrm{g} / \mathrm{mL}\right.$ versus $\left.52.52 \mu \mathrm{g} / \mathrm{mL}\right)$ and plasma $\left(I C_{50}=77.17 \mu \mathrm{g} / \mathrm{mL}\right.$ versus $190.81 \mu \mathrm{g} / \mathrm{mL}$ ). In the antihepatoma studies, POE showed a greater potency than $\alpha$-tocopherol in inhibiting Hep G2, Hep $3 B$ and PLC/PRF/5 cells. The antiproliferative effect of POE against these human hepatoma cells was dose-dependent, with $I C_{50}$ values varying from 4.86 to $68.44 \mu \mathrm{g} / \mathrm{mL}$. The present results demonstrate that POE is an effective natural antioxidant supplement for protecting cellular membranes against oxidative damage and inhibiting hepatoma cell proliferation.
\end{abstract}

${ }^{3}$ Corresponding author. TEL: +886-8-7624002 ext. 450; FAX: +886-8-7621645; EMAIL: 1thuang@ mail.tajen.edu.tw 


\section{INTRODUCTION}

In recent years, there has been an increased interest in the role of natural antioxidant as dietary supplements in preventing chronic and degenerative diseases (Halliwell 1997). Reactive oxygen species (ROS), including free radicals such as $\mathrm{O}_{2}{ }^{--}$(superoxide anion), $\bullet \mathrm{OH}$ (hydroxyl radical), $\mathrm{H}_{2} \mathrm{O}_{2}$ (hydrogen peroxide) and ${ }^{1} \mathrm{O}_{2}$ (singlet oxygen), can cause cellular injuries and also initiate peroxidation of polyunsaturated fatty acids in biological membranes. In general, ROS are generated for various physiological functions in the human body. Its overproduction is often overcome by the body's own antioxidant systems, including enzymatic and nonenzymatic antioxidants. The antioxidant enzymes (i.e., superoxide dismutase, catalase and glutathione peroxidase) are able to convert the excess ROS into nontoxic compounds (Young and Woodside 2001), whereas the nonenzymatic antioxidants such as vitamins $\mathrm{C}$ and $\mathrm{E}$, carotenoids, flavonoids, polyphenols and micronutrient elements (zinc and selenium) are believed to be responsible for free radical scavenging and inhibition of lipid peroxidation in the body (Polidori et al. 2001; Lee et al. 2003). When an imbalance between antioxidants and ROS occurs, the excessive oxidants may result in oxidative damage to biomolecules, i.e., lipids, DNA and proteins, and eventually lead to the occurrence of free radical-related diseases, including coronary heart disease, diabetes mellitus, rheumatic disease, cancer and others (Slater 1984; Halliwell 1997; Cheng et al. 2003). This is why the daily intake of natural foods and food-derived antioxidants is necessary, because they are known to function as chemopreventive agents against oxidative damage.

Hepatocellular carcinoma (HCC) is one of the most prevalent malignant diseases in China, Taiwan, Korea and Sub-Sahara Africa (Chen et al. 1996). The major cause of HCC widespread in Taiwan is known to result from hepatitis B virus infection (Harris 1990). Most patients diagnosed with HCC have low recovery rates, and conventional and modified therapies currently available are rarely beneficial (Harris 1990; Okuda 1992). Therefore, scientists continue to search for more effective antihepatoma agents from natural products.

Palm oil, an edible vegetable oil derived from the fruits of Elaeis guineensis, forms an important component of the human diet in different parts of the world. It has $50 \%$ saturated, $40 \%$ monounsaturated and $10 \%$ polyunsaturated fatty acids besides an abundant amount of phytonutrients (Clegg 1973; Manorama and Rukmini 1991). Recent studies have shown that palm oil and/or its antioxidant constituents are effective in controlling anthrosclerosis and certain types of cancer (Goh et al. 1994; Guthrie et al. 1997; Takahashi and Loo 2004), while no study has been conducted on hepatoma cells. Tocotrienols, which are active components of palm oil, are shown to be effective in 
preventing oxidative damage to lipids in vitro and in vivo (Serbinova et al. 1991; Nesaretnam et al. 1993; Tomeo et al. 1995). Furthermore, tocotrienolrich fraction (TRF) from palm oil was reported to be more potent than $\alpha$-tocopherol against oxidative damage in brain mitochondria (Kamat and Devasagayam 1995), and more effective in inhibiting protein oxidation and lipid peroxidation in liver microsomes (Nesaretnam et al. 1993). The objectives of this study were: (1) to evaluate the antioxidant activities of standardized POE in different model systems in rat tissues, as well as comparing them with $\alpha$-tocopherol; and (2) to examine the antiproliferative effect of POE against a series of human hepatoma cells, namely Hep G2, Hep 3B and $\mathrm{PLC} / \mathrm{PRF} / 5$.

\section{MATERIALS AND METHODS}

\section{Chemicals}

L-(+)-ascorbic acid, thiobarbituric acid (TBA), xanthine, xanthine oxidase and cytochrome $c$ were purchased from Sigma Chemical Co. (St. Louis, MO). $\alpha$-Tocopherol, dimethylsulfoxide (DMSO) and ferrous chloride were obtained from Wako Pure Chemical Industries (Osaka, Japan). Fetal bovine serum was purchased from GIBCO BRL (Gaithersburg, MD). The test solutions of POE and $\alpha$-tocopherol were freshly prepared for different experiments. All other chemicals used were of analytical grade.

\section{Test Animals}

Male Sprague-Dawley rats, about 6 weeks of age, were purchased from the Animal Center of the National Laboratory of Animal Breeding and Research Center (Taipei, Taiwan). They were housed in a controlled environment with temperature maintained at $22 \pm 3 \mathrm{C}$ and humidity at $55 \pm 5 \%$ under a 12:12 h light/dark cycle. Animals were fed a standard laboratory diet and tap water ad libitum until use. They were treated in accordance with the guidelines of the National and Institute's Animal Care Committee.

\section{Cell Culture}

The human hepatoma PLC/PRF/5 (ATCC CRL8024), Hep 3B (ATCC HB8064) and Hep G2 (ATCC HB 8065) cells were obtained from the American Type Culture Collection (Rockville, MD). The cells were cultured in Dulbecco's modified Eagle's medium (DMEM; Gibco, Grand Island, NY), supplemented with $10 \%$ fetal calf serum, 100 units penicillin G, $100 \mu \mathrm{g} / \mathrm{mL}$ 
streptomycin, and $0.25 \mu \mathrm{g} / \mathrm{mL}$ amphotericin B (Gibco) in an incubator with humidified air at $37 \mathrm{C}$ with $5 \% \mathrm{CO}_{2}$.

\section{Palm Oil Extracts (POE)}

A standardized POE was obtained from Carotech Ltd. (Ipoh, Malaysia). It consisted of $15.38 \% \quad \alpha$-tocotrienol, $28.20 \% \quad \gamma$-tocotrienol, $6.42 \%$ $\delta$-tocotrienol, $15.34 \% \alpha$-tocopherol, $12.82 \%$ plant squalene and $5.12 \%$ phytosterol. All experiments were conducted using aliquots of POE from the same batch to avoid any possible inconsistence because of batch to batch variation. POE and $\alpha$-tocopherol (as positive control) were dissolved in DMSO and further diluted with either phosphate buffer or cultured medium. The final DMSO concentration was $0.1 \%$.

\section{Preparation of Liver and Brain Homogenates}

On the test day, rats weighing about $200 \mathrm{~g}$ were sacrificed under ether anesthesia. Blood was obtained by cardiac puncture, followed by collecting the liver and brain samples. Two grams of liver and brain tissues was immediately removed and sliced into pieces. The tissue samples were homogenized with $10 \mathrm{~mL}$ of $150 \mathrm{mM} \mathrm{KCl}$-Tris-HCl buffer ( $\mathrm{pH}$ 7.2), and then centrifuged at $500 \times \mathrm{g}$ for $10 \mathrm{~min}$ to give a supernatant of liver or brain homogenate. The supernatant was collected and the protein content of the supernatant was determined by the method of Lowry et al. (1951).

\section{Plasma Sample Preparation}

Blood was centrifuged at $1,000 \times \mathrm{g}$ at $4 \mathrm{C}$ for $15 \mathrm{~min}$ to obtain a supernatant layer of plasma, which was collected and stored at $-80 \mathrm{C}$ until analysis.

\section{Free Radical Scavenging Activity Assay}

Free radical scavenging activity was assayed spectrophotometrically by the reduction of cytochrome $c$ method as described by McCord and Fridovich (1969). In brief, $10 \mathrm{mg}$ of POE or $\alpha$-tocopherol was dissolved in DMSO and further diluted with $50-\mathrm{mM}$ phosphate buffer $(\mathrm{pH}=7.8)$ to various concentrations ( 10 to $100 \mu \mathrm{g} / \mathrm{mL}$ ), then $20 \mu \mathrm{L}$ of 0.07 units $/ \mathrm{mL}$ xanthine oxidase, $300 \mu \mathrm{L}$ of $100-\mu \mathrm{M}$ xanthine and $15 \mu \mathrm{L}$ of $50-\mu \mathrm{M}$ cytochrome $c$ were added to these samples. They were vigorously mixed and then incubated for $3 \mathrm{~min}$ at room temperature, followed by spectrophotometric determination of the ferricytochrome $c$ reduction at $550 \mathrm{~nm}$.

\section{Xanthine Oxidase Inhibition Test}

Xanthine oxidase inhibition activity was estimated by the formation of uric acid from xanthine-xanthine oxidase system (Chang et al. 1994). Test 
samples were dissolved in DMSO, and then diluted with 50-mM phosphate buffer ( $\mathrm{pH}=7.8$ ) to various concentrations ( 1 to $100 \mu \mathrm{g} / \mathrm{mL}$ ). After $350 \mu \mathrm{L}$ of xanthine $(100 \mu \mathrm{M})$ and $20 \mu \mathrm{L}$ of xanthine oxidase $(0.4$ units) were added, samples were vigorously mixed and then incubated for $3 \mathrm{~min}$ at room temperature. Superoxide formation was counted by spectrophotometric measurement of uric acid production at $295 \mathrm{~nm}$.

\section{Antilipid Peroxidation Assay}

The effect of $\mathrm{POE}$ on $\mathrm{FeCl}_{2}$-ascorbic acid-induced lipid peroxidation in rat liver and brain homogenates, and plasma was determined by the method of Yoshiyuki et al. (1981). In brief, a reaction mixture containing $0.5 \mathrm{~mL}$ of liver or brain homogenate or plasma sample, $0.1 \mathrm{~mL}$ of Tris-HCl buffer $(\mathrm{pH}=7.2)$, $0.05 \mathrm{~mL}$ of $0.1-\mathrm{mM}$ ascorbic acid, $0.05 \mathrm{~mL}$ of $4-\mathrm{mM} \mathrm{FeCl}_{2}$, and $0.05 \mathrm{~mL}$ of various concentrations of POE or $\alpha$-tocopherol was mixed in a capped tube and then incubated for $1 \mathrm{~h}$ at $37 \mathrm{C}$. After incubation, $0.9-\mathrm{mL}$ distilled water and $2 \mathrm{~mL}$ of $0.6 \%$ TBA in distilled water were added and then shaken vigorously. The mixture was heated for $30 \mathrm{~min}$ in a boiling water bath at 100C. After cooling, $5 \mathrm{~mL}$ of $n$-butanol was added and the mixture was then shaken vigorously. The $n$-butanol layer was separated by centrifugation at $3,000 \times \mathrm{g}$ for $10 \mathrm{~min}$, followed by subjecting to the measurement of TBA reactive substances (TBARS) production at $532 \mathrm{~nm}$.

\section{Antihepatoma Activity Assay}

The inhibition of cell proliferation was assessed by sodium $3^{\prime}$ [1-(phenylamino-carbonyl)-3,4-tetrazolium]-bis(4-methoxy-6-nitro)benzenesulfonic acid hydrate (XTT; Sigma Chemical Co.) assay as described by Roehm et al. (1991) with modification. Briefly, cells were subcultured on a 96-well plate with $1 \times 10^{4}$ cells per well in $100-\mu \mathrm{L}$ medium. After $24 \mathrm{~h}$ of incubation, the medium in the 96-well plate was discarded and replaced with the medium containing different concentrations of POE or $\alpha$-tocopherol $(1-100 \mu \mathrm{g} / \mathrm{mL}$ ) or 5 -fluorouracil (5-FU; as positive control) or $0.1 \%$ DMSO (as negative control). The treated cells were incubated at $37 \mathrm{C}$ for $48 \mathrm{~h}$; each well then received $50 \mu \mathrm{L}$ of XTT test solution prepared by mixing $5 \mathrm{~mL}$ of XTT-labeling reagent $(1 \mathrm{mg} / \mathrm{mL}$ XTT in RPMI [Roswell Park Memorial Institute] 1640 medium) and $100 \mu \mathrm{L}$ of electron coupling reagent (phenazine methosulfate). After $4 \mathrm{~h}$ of incubation, the formazan production of sample was measured with an ELISA reader (Multiskan EX; Labsystems, Waltham, MA) at a test wavelength of $492 \mathrm{~nm}$ and a reference wavelength of $690 \mathrm{~nm}$.

Data were calculated as percentage of inhibition by the following formula: Inhibition $\%=(100-[\mathrm{ODt} / \mathrm{ODs}] \times 100) \%$. ODt and ODs indicated the optical density of test compounds and the solvent control, respec- 
tively. The $\mathrm{IC}_{50}$ value of the test substance, the concentration which gives $50 \%$ decrement of cell viability, was also calculated.

\section{Statistical Analysis}

Data were presented as means \pm SDs from three independent experiments. The statistical difference between $\alpha$-tocopherol and POE-treated groups was compared using Student's $t$-test. Differences were considered significant when $P$-value was $<0.05$.

\section{RESULTS}

\section{Free Radical Scavenging Activity}

Results showed that the superoxide anion scavenging activity of POE increased with increasing concentration of POE (Fig. 1). At concentrations of $0.1-10 \mu \mathrm{g} / \mathrm{mL}$, POE showed a scavenging rate ranging from 50.6 to $100.0 \%$ whereas $\alpha$-tocopherol varies from 27.3 to $97.4 \%$, with an $\mathrm{IC}_{50}$ value of $0.09 \mu \mathrm{g} / \mathrm{mL}$ for POE and $0.51 \mu \mathrm{g} / \mathrm{mL}$ for $\alpha$-tocopherol (Table 1). At a low concentration of $0.01 \mu \mathrm{g} / \mathrm{mL}$, the free radical scavenging activity of POE $(46.0 \%)$ was about threefold higher than $\alpha$-tocopherol (18.2\%). POE exhibited a scavenging effect of $50.6 \%$ at $0.1 \mu \mathrm{g} / \mathrm{mL}, 94.7 \%$ at $1 \mu \mathrm{g} / \mathrm{mL}$ and $100.0 \%$ at

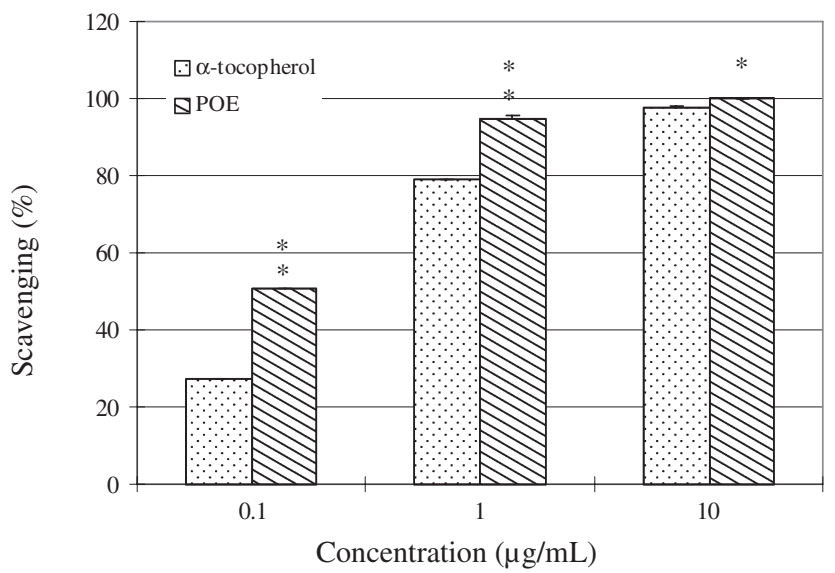

FIG. 1. SUPEROXIDE SCAVENGING ACTIVITY OF PALM OIL EXTRACT (POE)

Data present the percentage of free radical scavenging, means $\pm \mathrm{SD}(n=3)$; the asterisk indicates a significant difference between $\alpha$-tocopherol and POE-treated groups based on Student's $t$-tests $(* P<0.05 ; * * P<0.01)$. 
TABLE 1.

ANTIOXIDANT ACTIVITIES OF PALM OIL EXTRACT (POE)

\begin{tabular}{|c|c|c|c|c|c|}
\hline \multirow[t]{3}{*}{ Sample } & \multicolumn{5}{|c|}{$\mathrm{IC}_{50}$ values $(\mu \mathrm{g} / \mathrm{mL})^{*}$} \\
\hline & \multirow[t]{2}{*}{ Cytochrome $c$} & \multirow[t]{2}{*}{$\mathrm{XOI} \dagger$} & \multicolumn{3}{|c|}{ Antilipid peroxidation } \\
\hline & & & Liver & Brain & Plasma \\
\hline$\alpha$-tocopherol & 0.51 & 0.83 & 0.94 & 52.52 & 190.81 \\
\hline POE & 0.09 & 0.67 & 0.53 & 0.10 & 77.17 \\
\hline
\end{tabular}

$10 \mu \mathrm{g} / \mathrm{mL}$, which were more active than that of $\alpha$-tocopherol at the same concentrations. These results indicate that POE possesses a strong free radical scavenging activity.

\section{Xanthine Oxidase Inhibitory Activity}

Both POE and $\alpha$-tocopherol exhibited an inhibitory effect on xanthine oxidase activity in a concentration-dependent manner (Fig. 2). However, POE showed a stronger xanthine oxidase inhibition activity than $\alpha$-tocopherol at all concentrations tested, with an inhibition rate varying from 40.7 to $100.0 \%$. The $\mathrm{IC}_{50}$ value of $\mathrm{POE}$ was $0.67 \mu \mathrm{g} / \mathrm{mL}$, which is lower than $\alpha$-tocopherol $(0.83 \mu \mathrm{g} / \mathrm{mL})$ (Table 1$)$. The present results reveal that POE possesses a very potent xanthine oxidase inhibitory activity.

\section{Antilipid Peroxidation Activity}

The inhibitory effect of POE and $\alpha$-tocopherol on TBARS production in rat liver and brain homogenates, and plasma induced by $\mathrm{FeCl}_{2}$-ascorbic acid is shown in Fig. 3A,B,C. Results showed that the inhibition of TBARS formation increased with increasing concentrations of POE and $\alpha$-tocopherol. At concentrations of $0.1-100 \mu \mathrm{g} / \mathrm{mL}$, POE displayed an antilipid peroxidation activity ranging from 48.4 to $92.4 \%$ for liver, 50.0 to $91.8 \%$ for brain and 28.8 to $54.7 \%$ for plasma. Among the three different biological samples tested, the antilipid peroxidation effect of $\mathrm{POE}$ on plasma was moderate. The $\mathrm{IC}_{50}$ values revealed that $\mathrm{POE}$ was more effective in inhibiting lipid peroxidation than $\alpha$-tocopherol in liver $\left(\mathrm{IC}_{50}=0.53 \mu \mathrm{g} / \mathrm{mL}\right.$ versus $0.94 \mu \mathrm{g} / \mathrm{mL}$ ), brain $\left(\mathrm{IC}_{50}=0.10 \mu \mathrm{g} / \mathrm{mL}\right.$ versus $\left.52.52 \mu \mathrm{g} / \mathrm{mL}\right)$ and plasma $\left(\mathrm{IC}_{50}=77.17 \mu \mathrm{g} / \mathrm{mL}\right.$ versus $190.81 \mu \mathrm{g} / \mathrm{mL}$ ) (Table 1). 


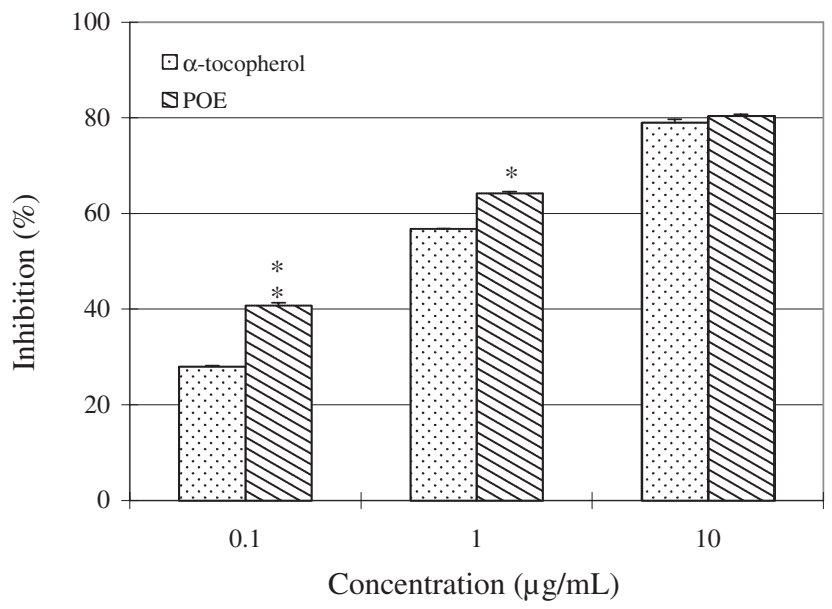

FIG. 2. XANTHINE OXIDASE INHIBITION ACTIVITY OF PALM OIL EXTRACT (POE) Data present the percentage of inhibition on the xanthine oxidase activity, means $\pm \mathrm{SD}(n=3)$; the asterisk indicates a significant difference between $\alpha$-tocopherol and POE-treated groups based on Student's $t$-tests $(* P<0.05 ; * * P<0.01)$.

\section{Antihepatoma Activity Assay}

To evaluate the effect of POE on human hepatoma cell proliferation, we assessed the activities of POE at different concentrations $(1-100 \mu \mathrm{g} / \mathrm{mL})$ on Hep G2, Hep 3B and PLC/PRF/5 cells. As shown in Fig. 4, both POE and $\alpha$-tocopherol exhibited an antiproliferative effect on all cell lines tested in a dose-dependent manner. However, a greater potency was noted in the POEtreated hepatoma cell lines, with $\mathrm{IC}_{50}$ values of $8.10 \mu \mathrm{g} / \mathrm{mL}$ for Hep G2, $68.44 \mu \mathrm{g} / \mathrm{mL}$ for Hep 3B and $4.86 \mu \mathrm{g} / \mathrm{mL}$ for PLC/PRF/5. Interestingly, POE also showed a stronger potency than 5-FU (a commercial anticancer drug) against PLC/PRF/5 cells (Table 2).

\section{DISCUSSION}

The present study demonstrated that POE effectively scavenged superoxide radicals and lipid peroxides, which are the major forms of ROS generated in the human body. It also exhibited strong antiproliferative effects against human hepatoma Hep G2, Hep 3B and PLC/PRF/5 cells. These findings suggest that POE might exert its pharmacological activities through quenching excessive free radicals and attenuating the oxidative stress. This also indicates that POE containing a mixture of both tocotrienols and 

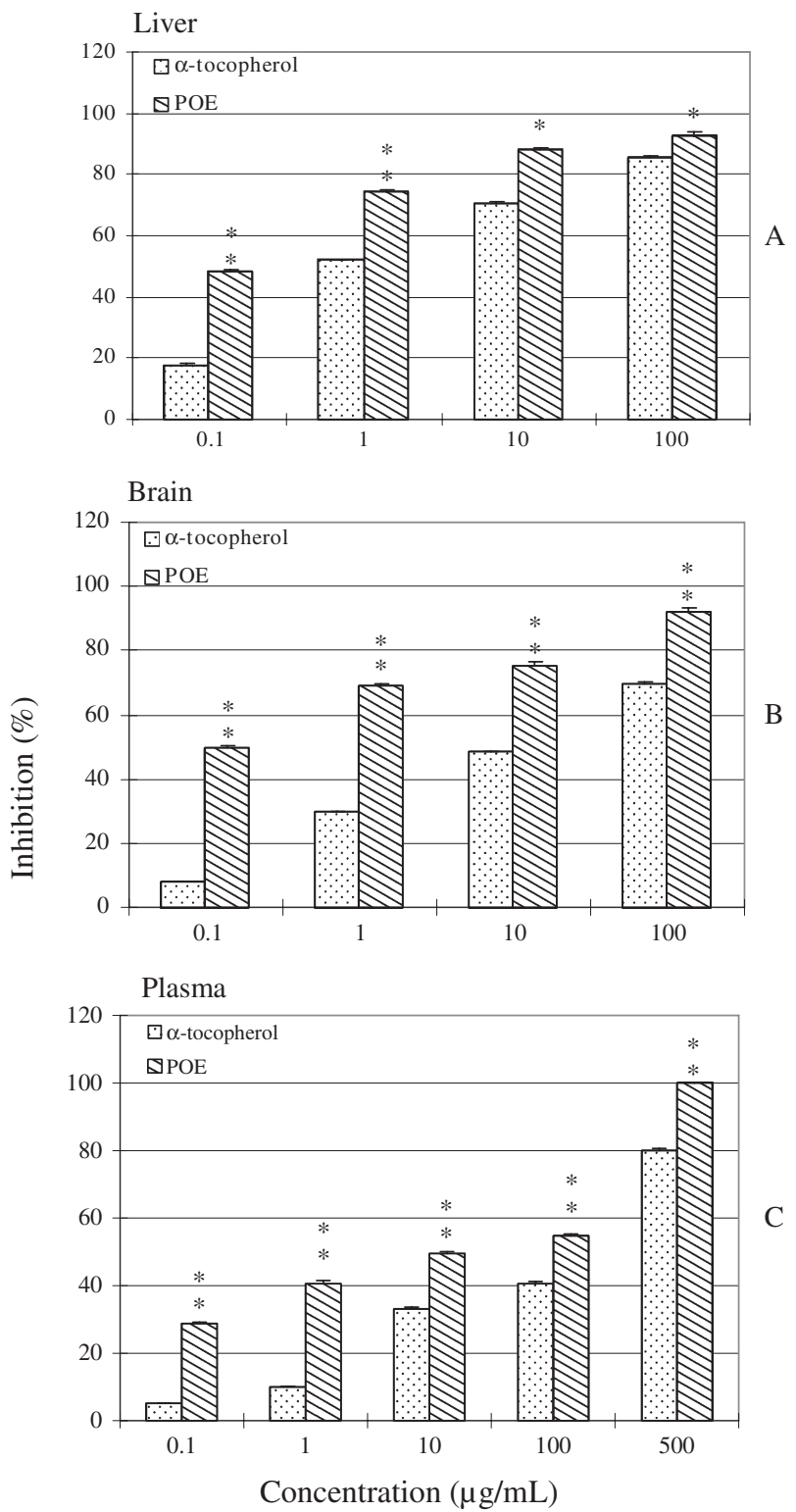

FIG. 3. INHIBITORY EFFECT OF PALM OIL EXTRACT (POE) ON $\mathrm{FeCl}_{2}$-ASCORBIC ACID-INDUCED THIOBARBITURIC ACID-REACTIVE SUBSTANCES (TBARS) PRODUCTION IN DIFFERENT RAT TISSUES

(A) Liver, (B) brain and (C) plasma. Values present means $\pm \mathrm{SD}(n=5)$; the asterisk indicates a significant difference between $\alpha$-tocopherol and POE-treated groups based on Student's $t$-tests $(* P<0.05 ; * * P<0.01)$. 

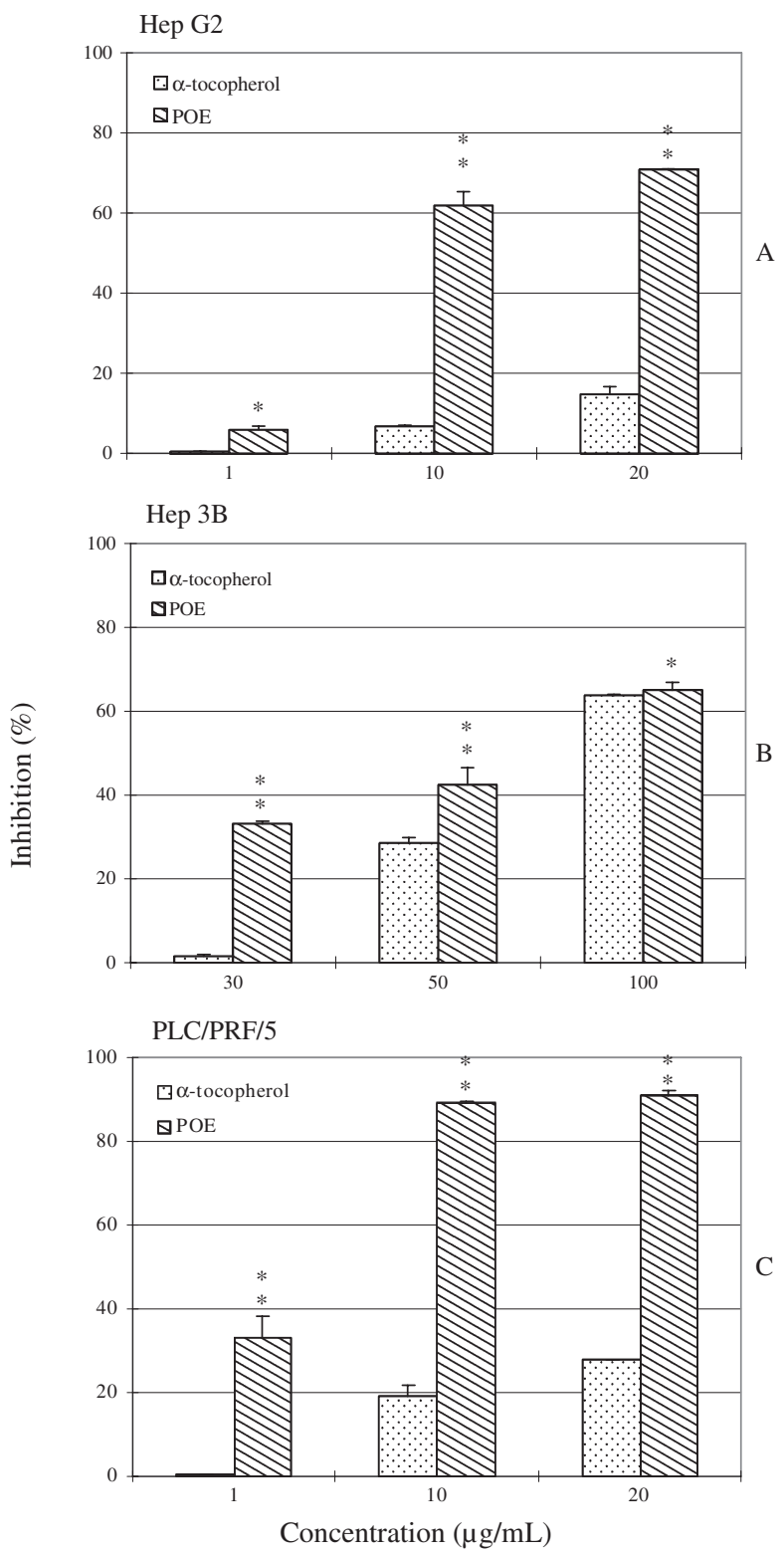

FIG. 4. ANTIPROLIFERATIVE EFFECTS OF PALM OIL EXTRACT (POE) AND $\alpha$-TOCOPHEROL ON HEPATOMA CELL LINES

(A) HEP G2, (B) HEP 3B and (C) PLC/PRF/5. Antiproliferative effects were determined by XTT assay. Values present means $\pm \mathrm{SD}(n=5)$; the asterisk indicates a significant difference between $\alpha$-tocopherol and POE-treated groups based on Student's $t$-tests $(* P<0.05 ; * * P<0.01)$. 
TABLE 2.

ANTIHEPATOMA ACTIVITIES OF PALM OIL EXTRACT (POE)

\begin{tabular}{lccc}
\hline & \multicolumn{3}{c}{$\mathrm{IC}_{50}$ values $(\mu \mathrm{g} / \mathrm{mL})^{*}$} \\
\cline { 2 - 4 } & Hep G2 & Hep 3B & PLC/PRF/5 \\
\hline$\alpha$-tocopherol & 100 & 84.04 & $>100$ \\
POE & 8.10 & 68.44 & 4.86 \\
5 -FU $\dagger$ & 5.27 & 10.45 & 7.66 \\
\hline * Values are expressed as means \pm SD of three independent experi- \\
ments. IC S0 $_{50}$ is the drug concentration which gives 50\% decrement \\
of cell viability. \\
$\dagger$ 5-FU, 5-fluorouracil (a commercial anticancer drug).
\end{tabular}

$\alpha$-tocopherol is more efficient than $\alpha$-tocopherol alone in the protection of biological tissues against oxidative stress.

The strong antioxidant activity demonstrated by POE may be contributed by the lipid antioxidants (tocotrienols, tocopherols and phytosterols). These bioactive components have been shown to possess activities such as neuroprotective (Sen et al. 2000; Osakada et al. 2004), anticancer (Goh et al. 1994; Conte et al. 2004; Sylvester et al. 2005) and cardiovascular protective effects (Qureshi et al. 1995; Tomeo et al. 1995), and lowering blood cholesterol level (Qureshi et al. 1995; Minhajuddin et al. 2005). The observed antilipid peroxidation inhibitory effect of POE was also consistent with other observations on the antioxidant effect of TRF given to rats as a dietary component on lipid peroxidation in rat liver subcellular fractions (Nesaretnam et al. 1993). Peroxidation of membrane lipids can inactivate cellular components and can have serious effects on human health. Preservation of cellular membrane integrity depends on the repair mechanisms that are capable of neutralizing oxidative reactions. Therefore, consumption of POE as a dietary supplement could potentially provide therapeutic benefits in preventing free radical-related diseases, such as neuronal disorders, cancer and cardiovascular diseases.

Recently, diets rich in fruits and vegetables have been considered excellent sources of antioxidants (Block et al. 1992; Nees and Powles 1997). Vitamins $\mathrm{C}$ and $\mathrm{E}$, polyphenols and carotenoids are thought to be responsible for most of the antioxidant activities in foods (Jialal et al. 1990; Esterbauer et al. 1991). $\alpha$-Tocopherol, a natural antioxidant, is well known to function as a free-radical quencher in cell membranes to protect against lipid peroxidation (Hafeman and Hoekstra 1977). It has also been shown to decrease atherosclerosis and delay death from myocardial infarction (Byers and Bowman 1993). In this study, POE was shown to possess a better antioxidant action than 
$\alpha$-tocopherol in all model systems tested, suggesting that POE is a better antioxidant in scavenging free radicals and preventing free radical damage to cell membranes.

Brain, due to its high oxygen consumption and abundant lipid-rich neural parenchyma, is extremely susceptible to oxidative damage (Kamat and Devasagayam 1995). This study shows that lipid peroxidation in the brain homogenate is significantly decreased by POE. Even at a low concentration of $0.1 \mu \mathrm{M} / \mathrm{mL}$, POE was quite effective in inhibiting lipid peroxidation in brain homogenate and was more active than $\alpha$-tocopherol. The higher antioxidant ability of POE could be explained by the fact that tocotrienols, which are major bioactive components of POE, are more mobile and less restricted in their interaction with lipid radicals in membranes than tocopherols (Serbinova et al. 1991).

In cell culture system, tocotrienols have been shown to possess chemopreventive effects against human estrogen-responsive MCF7 and estrogen-nonresponsive 435 (Guthrie et al. 1997; Sylvester et al. 2005), and MDA-MB-231 (Takahashi and Loo 2004) breast cancer cells, murine B16 melanoma cells (He et al. 1997), leukemia cells (Mo and Elson 1999), Raji cells (Goh et al. 1994) and PC3 and LNCaP prostate cancer cells (Conte et al. 2004). However, it has never been evaluated on hepatoma cell lines. Hence in this study, its antiproliferative effect against three different human hepatoma cell lines, namely Hep G2, Hep 3B and PLC/PRF/5 was examined. Results showed that POE possesses a better antihepatoma activity than $\alpha$-tocopherol. It was also surprising to note that the potency of POE was better than 5-FU on PLC/PRF/5 cells. Although the exact mechanism of POE in inhibiting hepatoma cell proliferation and triggering hepatoma cell apoptosis is yet to be evaluated, it is possible that the redox state of mitochondria might play a crucial role in carcinogenesis of hepatoma cells (Sreedhar et al. 2002; Shi et al. 2003; Takahashi and Loo 2004). Patients with liver cancer or other neoplastic diseases were shown to have a chaotic antioxidative system. When antioxidants such as vitamins $\mathrm{A}, \mathrm{C}$ and $\mathrm{E}$ or certain natural antioxidants were used to assist in the treatment, a positive effect on lowering the level of lipid peroxides and infection rate of the postoperative liver was noted (Factor et al. 2001; Woodson et al. 2002). In this study, POE effectively inhibited hepatoma cell proliferation, suggesting that extracts such as POE, which possesses strong antioxidant properties, could have contributed to the antihepatoma activity.

Earlier studies have shown that rats fed with palm oil diets have a lower incidence of mammary cancers than those fed with other dietary fats, and these results were partly attributed to the presence of carotenoids or tocopherols and tocotrienols (Sundram et al. 1989). In this study, POE showed a stronger inhibitory effect on hepatoma cell proliferation, with a potency three- to fourfold greater than $\alpha$-tocopherol was noted in Hep G2 and PLC/PRF/5 cells. 
This finding suggests that tocotrienols could be an important factor in the suppression of carcinogenesis. Besides natural antioxidants such as flavonoids and phenolic compounds, tocotrienols are also present in many plants, which may partly explain why dietary intake of fruit and vegetables is protective against cancer (Komiyama et al. 1989; Goh et al. 1994) and other degenerative diseases.

In conclusion, POE showed a more potent antilipid peroxidation and free radical scavenging activities than $\alpha$-tocopherol in all tested models. POE also exhibited a greater antiproliferative effect than $\alpha$-tocopherol against the three hepatoma cell lines tested, with $\mathrm{IC}_{50}$ lower than $10 \mu \mathrm{g} / \mathrm{mL}$ on Hep G2 and PLC/PRF/5 cells. POE and its individual active components therefore merit further investigation. These active components, in the form of extract, could be a better choice as antioxidant than $\alpha$-tocopherol for use in human diets or as dietary supplements to reduce oxidative damage and chronic degenerative diseases.

\section{REFERENCES}

BLOCK, G., PATTERSON, B. and SUBER, A. 1992. Fruits, vegetables and cancer prevention: A review of the epidemiological evidence. Nutr. Cancer 18, 1-29.

BYERS, T. and BOWMAN, B. 1993. Vitamin E supplements and coronary heart disease. Nutr. Rev. 51, 333-336.

CHANG, W.S., Chang, Y.H., LU, F.J. and CHIANG, H.C. 1994. Inhibitory effects of phenolics on xanthine oxidase. Anticancer Res. 14, 501-506.

CHEN, X.H., HU, Y.M. and LIAO, Y.Q. 1996. Protective effects of tetrandrine on $\mathrm{CCl}_{4}$-injured hepatocytes. Zhongguo Yao Li Xue Bao 17, 348-350.

CHENG, H.Y., LIN, T.C., YU, K.H., YANG, C.M. and LIN, C.C. 2003. Antioxidant and free radical scavenging activities of Terminalia chebula. Biol. Pharm. Bull. 26, 1331-1335.

CLEGG, A.J. 1973. Composition and related nutritional and organoleptic aspects of palm oil. J. Am. Oil Chem. Soc. 50, 321-324.

CONTE, C., FLORIDI, A., AISA, C., PIRODDI, M., FLORIDI, A. and GALLI, F. 2004. Gamma-tocotrienol metabolism and antiprolerative effect in prostate cancer cells. Ann. N.Y. Acad. Sci. 1031, 391-394.

ESTERBAUER, H., DIEBER-ROTHENEDER, M., STRIEGL, G. and WAEG, G. 1991. Role of vitamin E in preventing the oxidation of lowdensity lipoprotein. Am. J. Clin. Nutr. 53, 314S-321S.

FACTOR, V.M., LASKOWSKA, D., JENSEN, M.R., WOITACH, J.T., POPESCU, N.C. and THORGEIRSSON, S.S. 2001. Vitamin E reduces chromosomal damage and inhibits hepatic tumor formation in a transgenic mouse model. Proc. Natl. Acad. Sci. USA 97, 2196-2201. 
GOH, S.H., HEW, N.F., NORHANOM, A.W. and YADAV, M. 1994. Inhibition of tumour promotion by various palm oil tocotrienols. Int. J. Cancer 57, 529-531.

GUTHRIE, N., GAPOR, A., CHAMBERS, A.F. and CARROLL, K.K. 1997. Inhibition of proliferation of estrogen receptor-blnegative MDAMB-435 and -positive MCF-7 human breast cancer cells by palm oil tocotrienols and tamoxifen, alone and in combination. J. Nutr. 127, 544S-548S.

HAFEMAN, D.G. and HOEKSTRA, W.G. 1977. Lipid peroxidation in vivo during vitamin $\mathrm{E}$ and selenium deficiency in the rat as monitored by ethane evolution. J. Nutr. 107, 666-672.

HALLIWELL, B. 1997. Antioxidants and human disease: A general introduction. Nutr. Rev. 55, S44-S52.

HARRIS, C.C. 1990. Hepatocellular carcinogenesis: Recent advances and speculations. Cancer Cell 2, 146-148.

HE, L., MO, H., HADISUSILO, S., QURESHI, A.A. and ELSON, C.E. 1997. Isoprenoids suppress the growth of murine B16 melanomas in vitro and in vivo. J. Nutr. 127, 668-674.

JIALAL, I., VEGA, G.L. and GRUNDY, S.M. 1990. Physiological levels of ascorbate inhibit the oxidative modification of low-density lipoprotein. Atherosclerosis 82, 185-191.

KAMAT, J.P. and DEVASAGAYAM, T.P.A. 1995. Tocotrienols from palm oil as potent inhibitors or lipid peroxidation and protein oxidation in rat brain mitochondria. Neurosci. Lett. 195, 179-182.

KOMIYAMA, K., IIZUKA, K., YAMAOKA, M., WATANABE, H., TSUCHIYA, N. and UMEZAWA, I. 1989. Studies on the biological activity of tocotrienols. Chem. Pharm. Bull. 37, 1369-1371.

LEE, S.E., SHIN, H.T., HWANG, H.J. and KIM, J.H. 2003. Antioxidant activity of extracts from Alpinia katsumadai seed. Phytother. Res. 17, 1041-1047.

LOWRY, O.H., ROSEBROUGH, N.J., FARR, A.L. and RANDALL, R.J. 1951. Protein measurement with the folin phenol reagent. J. Biol. Chem. 193, 265-275.

MANORAMA, R. and RUKMINI, C. 1991. Nutritional evaluation of crude palm oil in rats. Am. J. Clin. Nutr. 53, 1031S-1033S.

MCCORD, J.M. and FRIDOVICH, I. 1969. Superoxide dismutase: An enzymic function for erythrocuprein (hemocaprein). J. Biol. Chem. 244, 6049-6055.

MINHAJUDDIN, M., BEG, Z.H. and IQBAL, J. 2005. Hypolipidemic and antioxidant properties of tocotrienol rich fraction isolated from rice bran oil in experimentally induced hyperlipidemic rats. Food Chem. Toxicol. $43,747-753$. 
MO, H. and ELSON, C.E. 1999. Apoptosis and cell cycle arrest in human and murine tumor cells are initiated by isoprenoids. J. Nutr. 129, 804-813.

NEES, A.R. and POWLES, J.W. 1997. Fruit and vegetables, and cardiovascular disease: A review. Int. J. Epidemiol. 26, 1-13.

NESARETNAM, K., DEVASAGAYAM, T.P.A., SINGH, B.B. and BASIRON, Y. 1993. Influence of palm oil or its tocotrienol-rich fraction on the lipid peroxidation potential of rat liver mitochondria and microsomes. Biochem. Mol. Biol. Int. 30, 159-167.

OKUDA, K. 1992. Hepatocellular carcinoma: Recent progress. Hepatology 15, 948-963.

OSAKADA, F., HASHINO, A., KUME, T., KATSUKI, H., KANEKO, S. and AKAIKE, A. 2004. $\alpha$-Tocotrienol provides the most potent neuroprotection among vitamin $\mathrm{E}$ analogs on cultured striatal neurons. Neuropharmacology 47, 904-915.

POLIDORI, M.C., STAHL, W., EICHLER, O., NIESTROJ, I. and SIES, H. 2001. Profiles of antioxidants in human plasma. Free Radical Biol. Med. 30, 456-462.

QURESHI, A.A., BRADLOW, B.A., BRACE, L., MANGANELlO, J., PETERSON, D.M., PEARCE, B.C., WRIGHT, J.J.K., GAPOR, A. and ELSON, C.E. 1995. Response of hypercholesterolemic subjects to administration to tocotrienols. Lipids 30, 1171-1177.

ROEHM, N.W., RODGERS, G.H., HATFIELD, S.M. and GLASEBROOK, A.L. 1991. An improved colorimetric assay for cell proliferation and viability utilizing the tetrazolium salt XTT. J. Immunol. Methods 142, 257-265.

SEN, C.K., KHANNA, S., ROY, S. and PACKER, L. 2000. Molecular basis of vitamin $\mathrm{E}$ action. Tocotrienol potently inhibits glutamate-induced pp60(c-Src) kinase activation and death of HT4 neuronal cells. J. Biol. Chem. 275, 13049-13055.

SERBINOVA, B., KAGAN, Y., HAN, D. and PACKER, L. 1991. Free radical recycling and intramembrane mobility in the antioxidant properties of alpha-tocopherol and alpha-tocotrienol. Free Radical Biol. Med. 10, 263275.

SHI, D.Y., DENG, Y.R., LIU, S.L., ZHANG, Y.D. and WEI, L. 2003. Redox stress regulates cell proliferation and apoptosis of human hepatoma through Akt protein phosphorylation. FEBS Lett. 542, 60-64.

SLATER, T.F. 1984. Free-radical mechanisms in tissue injury. Biochem. J. $222,1-15$.

SREEDHAR, A.S., PARDHASARADHI, B.V.V., KHAR, A. and SRINIVAS, U.K. 2002. A cross talk between cellular signaling and cellular redox state during heat-induced apoptosis in a rat histiocytoma. Free Radical Biol. Med. 32, 221-227. 
SUNDRAM, K., KHOR, H.T., ONG, A.S. and PATHMANATHAN, R. 1989. Effect of dietary palm oils on mammary carcinogenesis in female rats induced by 7,12-dimethylbenz(a)anthracene. Cancer Res. 49, 14471451.

SYLVESTER, P.W., SHAH, S.J. and SAMANT, G.V. 2005. Intracellular signaling mechanisms mediating the antiproliferative and apoptotic effects of gamma-tocotrienol in neoplastic mammary epithelial cells. J. Plant Physiol. 162, 803-810.

TAKAHASHI, K. and LOO, G. 2004. Disruption of mitochondria during tocotrienol-induced aopotosis in MDA-MB-231 human breast cancer cells. Biochem. Pharmacol. 67, 315-324.

TOMEO, A.C., GELLER, M., WATKINS, T.R., GAPOR, A. and BIERENBAUM, M.L. 1995. Antioxidant effects of tocotrienols in patients with hyperlipidermia and carotid stenosis. Lipids 30, 1179-1183.

WOODSON, K., TRIANTOS, S., HARTMAN, T., TAYLOR, P.R., VIRTAMO, J. and ALBANES, D. 2002. Long-term alpha-tocopherol supplementation is associated with lower serum vascular endothelial growth factor levels. Anticancer Res. 22, 375-378.

YOSHIYUKI, K., MICHINORI, K., TADATO, T., SHIGERU, A. and HIROMICHI, O. 1981. Studies on Scutellariae radix. IV. Effects on lipid peroxidation in rat liver. Chem. Pharm. Bull. 29, 2610-2617.

YOUNG, I.S. and WOODSIDE, J.V. 2001. Antioxidants in health and disease. J. Clin. Pathol. 54, 176-186. 